\title{
Die waarde van tolking vir tersiêre onderrig en leer. 'n Ondersoek na die persepsies van tolkgemedieerde kommunikasie in die Fakulteit Regsgeleerdheid aan die Universiteit Stellenbosch
}

\author{
Carmen Brewis \\ Departement Afrikaans en Nederlands, Universiteit Stellenbosch, Suid-Afrika \\ E-pos: Carmen.brewis@gmail.com
}

\section{Opsomming}

Hierdie artikel is gegrond op 'n Meesterstudie wat die onderwerp was van 'n M-tesis in Tolkstudie. Die studie het spesifiek 'n bydrae gemaak tot die bestaande navorsing in Opvoedkundige tolking. Simultane (gesproke) opvoedkundige tolking het relatief onlangs as aparte subdomein van gemeenskapstolking in Suid-Afrika beslag gevind. Navorsing hier te lande verteenwoordig pionierswerk in hierdie ontluikende studieveld. Een van die belangrikste kwessies waarin beleidsmakers en opvoeders belangstel, is die effektiwiteit van opvoedkundige tolking vir onderrig en leer. Die navorser het 'n ondersoek na hierdie vraagstuk onderneem en die persepsies van dosente, studente en tolke getoets ten einde antwoorde op die volgende twee vrae te vind:

- Wat is die ervaring van opvoedkundige tolking in klaskamers binne die konteks van die Fakulteit Regsgeleerdheid aan die Universiteit Stellenbosch? en;

- Wat is die waarde wat opvoedkundige tolking vir onderrig en leer binne hierdie konteks kan inhou?

Die T-opsie geld as die verstektaalopsie binne die Fakulteit Regsgeleerdheid. Die ervaring van tolking in klasse is telkens na aanleiding van die navorsingsvrae vergelyk met studente en dosente se ervaring van die T-opsie ten einde afleidings te maak oor die moontlike waarde van tolking binne hierdie konteks. Die unieke aard en die integrale rol wat taal en taalvaardighede in dié vakdissipline speel, maak hierdie konteks verder uniek en moes in die studie verreken word.

Die ondersoek is gedoen met verwysing na kontemporêre idees uit akademiese geletterdheidstudies. Konsepte soos affek, identiteit, toeganklikheid en deelname is verken om uiteindelik die verbande tussen opvoedkundige tolking en onderrig en leer te ondersoek en te beskryf. Die studie is gedoen teen die agtergrond van ' $n$ verkenning van die teorie in Tolkstudie met verwysing na rol, kwaliteit en professionaliteit sowel as resente navorsing uit die veld van gebaretaal. 
Die proefneming is in twee modules oor 'n tydperk van vier weke (16 uur) in klasse gedoen met verwysing na drie basiese vrae:

- Kan tolking in klasse studente help om vakinhoud beter te verstaan?

- Kan studente hierdeur beter met die klaskamersituasie identifiseer?

- Word tyd sodoende in die leerproses bespaar?

Deur ' $n$ proses van deelnemende aksienavorsing is data ingewin deur middel van vraelyste, 'n fokusgroepbespreking, onderhoude en waarneming. As navorsingsmetodologie het die navorser van beide kwalitatiewe en kwantitatiewe metodes gebruik gemaak.

Die basiese bevindinge was dat akademiese taalvaardighede van studente aansienlik verskil met beduidend groter taalvaardigheidsverskille onder Engelssprekende studente. Daar is 'n beduidende ontevredenheid met die T-opsie onder studente en dosente. Tolking is beduidend positief ervaar onder studente wat probleme met taal in die klaskamer ervaar, omdat dit gelei het tot ' $\mathrm{n}$ groter begrip van vakinhoud, die mak van meer omvattende aantekeninge tydens lesings en die feit dat studente tyd bespaar het in die leerproses. Studente voel nou meer tuis in die klaskameropset wat aanduidend was van wat navorsers in akademiese geletterdheidstudies beskryf as die reis van die "periferie" van geletterdheid na die "kern" daarvan. Verder was dit uit die studie duidelik dat tolking optimaal binne 'n eentalige konteks plaasvind en dat gehaltetolking ' $n$ voorvereiste is. Tolke moet verkieslik oor tolkervaring, kennis van klaskamerdiskoers en vakkennis, beskik. Suksesvolle kommunikasie, naamlik om te verstaan en om verstaan te word, bly 'n kernvoorwaarde vir leer.

Sleutelwoorde: tolking, opvoedkundige tolking, klaskamertolking, onderrig en leer, akademiese geletterdheid

The value of interpreting in a tertiary teaching and learning environment. An investigation into the perceptions of interpreter-mediated communication in the Faculty of Law at Stellenbosch University

\section{Extended abstract}

Educational Interpreting (spoken) has only fairly recently been established in South Africa as a separate sub-domain of community interpreting. Local research represents pioneering work in this emerging discipline. One of the most important issues that interests policy makers and teachers, is the effectiveness of educational interpreting for teaching and learning. This article makes a contribution towards the existing body of knowledge on Educational Interpreting (EI) by considering the role of interpreting-mediated communication in a tertiary teaching and learning context. It is based on a dissertation that was submitted for a Master's degree in Interpreting Studies (IS). The writer conducted an investigation in the Faculty of Law of Stellenbosch University into how educational interpreting is perceived by lecturers, students and interpreters and whether it can promote teaching and learning in the context. This article is a synopsis of that study. Educational Interpreting is herein firstly placed as subtype within the broader field of IS. This is followed by a brief discussion of "role" in IS and of contemporary ideas from Academic Literacy Studies (ALS). After a short explanation of the methodology that was used to conduct the investigation, the results are discussed. Finally certain recommendations are made for interpreting in university classrooms. 
Theoretical concepts from IS as well as recent research from the field of Sign Language Interpreting (SLI) formed the basis of the dissertation and are briefly discussed. Existing research on EI in a tertiary educational environment also brought valuable insights into how specific attributes of educational interpreters differ from those of conference interpreters. The differences between communication in a university classroom and other types of communication arrangements is considered and how this has a bearing on the typology of the interpreting and the style of the interpretation. Academic literacy lies on the interface between language and learning and therefore an investigation into contemporary ideas from (ALS) such as affect, identity, access and participation provides a valuable vantage point for an investigation into the role of EI in the context of the study. To be academically literate implies "knowing how to act and speak in academic discourses". In this journey from the periphery of knowledge to the center of the discipline, liberating literacy is considered the final goal. Here the student finally becomes an insider in the discourse and can start taking part as a full participant.

This article discusses the unique role played by educational interpreters and how they contribute to the process of "meaning-making" in the classroom. This is done by acting as "clarifiers" and by making links and relationships between ideas overt. Apart from remedying the cultural "noise" in the communication, it is also done through their ability to reflect on talk and to see, due to their position "in the middle", when speakers speak on different discourse trajectories. Interpreters further help to create a common culture between participants and to reduce the asymmetry that exists specifically in a tertiary educational context. This role can help to restore trust between the speakers. Interpreting makes mother tongue education possible. With reference to the importance of mother tongue education, this article discusses how EI plays a role in enhancing teaching and learning in the study context.

The Faculty of Law of Stellenbosch University has the T-option as default language option in classrooms. Therefore, this study tested perceptions of interpreting with reference to the research questions and compared it throughout with perceptions of the T-option.

\section{Methodology}

The trial was conducted in two modules during a four-week (16 hours) period, with specific reference to three basic questions namely:

- Can interpreting help students to understand subject content better?

- Can interpreting help students to better identify with the classroom situation?; and

- What is the effect of interpreting on time management in the learning process?

Two modules were identified for the trial, namely Private Law 373 (Law of Delicts) and Private Law 171 (Family Law) as respectively Group A (137 respondents) and Group B (12 respondents). Group B, a first-year group, served as a supplementary qualitative component to the study and provided valuable insights compared with the respondents from Group A, who were already in their third year.

Data was collected through a process of Participatory Action Research using questionnaires, a focus group discussion, interviews and observation. This research perspective was optimal in order to gain an insider perspective in a bottom-up process of data collection. As research methodology the researcher made use both of quantitative and qualitative methods. 
Questionnaires that were handed out to the respondents in Group A contained both quantitative Likert-scale questions as well as "open" questions eliciting qualitative data. A focus-group discussion was held with the users of the interpreting service as well as semi-structured interviews with the lecturers and the interpreter. The interviews generated valuable qualitative data. Group B received a short questionnaire with mainly open questions comprising another qualitative component. Mixed-method research allows for triangulation. This results in more reliable data, where conclusions cannot merely be attributed to methodology.

The predominant findings of the study are reported, first with reference to the T-option and then the interpreting. The quantitative (statistical) data (Group A) is firstly discussed followed by the qualitative data from the open questions, the interviews and the observation.

\section{Quantitative results}

With regard to academic language proficiency it was evident that there is a significant difference between language proficiency in the two languages of instruction among students from group A. In a statistical comparison between the Afrikaans and the English-speaking groups, it was clear that the difference in proficiency was significantly larger among Englishspeaking students.

\section{T-option}

Although a large number of respondents in Group A reported a positive experience of the Toption, there were a significant number of respondents who reported a negative experience. Statistical data are reported with reference to various aspects e.g. time-management in T-option classes, the taking of notes during lectures, the extent to which lecture content is understood in T-option classes including paralinguistic information like sarcasm, irony and jokes, the ability to identify with the learning environment and how respondents feel about the treatment of the two different languages in classes. Group A was further asked whether they see interpreting as "necessary" in their Faculty and whether it could, in their opinion, provide a sustainable solution to language issues in the Faculty. Statistical comparisons (hypothesis-testing) between the usergroup and the non-user group are reported as well as differences between the Afrikaans and the English group. P-values and standard deviations are given.

\section{Educational interpreting}

The reporting of data with reference to the EI mainly follows the same format as for the Toption. The data confirmed that EI was experienced largely positively by students who struggle with language in classrooms. Respondents were asked to indicate whether they would make use of the interpreting if such a service is provided. Statistical correlations done according to the Spearman-correlation indicated significant relationships between certain aspects. Through these it was evident that the more negative a respondent was towards the T-option, the more positive the response tended to be towards interpreting and vice versa. It also showed that the bigger the difference in language proficiency between first and second languages, the more positive interpreting is experienced.

\section{Qualitative results}

The qualitative results brought highly valuable insights into the true experiences of students and lecturers. While students have both positive and negative views on the T-option, there is a strong view that this option is time consuming, that there is too much repetition and that information is lost in the case of poor academic proficiency in the second language. Lecturers 
reported a frustration with the T-option. Their experience of the interpreting was positive. They did not find it to be a nuisance at all. Students reported that notes were more extensive and largely expressed relief on the availability of interpreting in their class. There was a marked improvement in time management both inside the classroom and during self-study. Among the users of the interpreting, the negative experiences were mainly reported by the Afrikaansspeaking students who feel that they have a sufficient understanding of English and that they do not need the interpreting service.

Valuable data was gathered through observation of T-option classes and brought insights into the most effective application of interpreting in the various modes of language delivery. It was evident that interpreting optimally takes place in a monolingual context and that quality interpreting is a pre-requisite for effective interpreting in a tertiary teaching and learning environment. Interpreters should ideally have knowledge of the subject content and of classroom discourse. Good co-operation between interpreters, lecturers and students is imperative. Interpreters should have the confidence to "intervene" in the communication and play an active role if this is required for optimal communication. They should furthermore be treated as communication participants with full status. The article closes with a quote from Courtney Cazden's seminal work Classroom Discourse (2001): “One condition essential to learning must remain the same: to communicate, to understand and to be understood - this condition has to be kept constant despite differences."

Keywords: interpreting, educational interpreting, classroom interpreting, teaching and learning, academic literacy

\section{Inleiding}

Aan die Universiteit Stellenbosch (US) is die ontwerp en implementering van 'n taalbeleid en -plan wat die uiteenlopende belange van kennis deur leer in meertalige klaskamers moet dien, 'n steeds ontwikkelende proses. Die leeromgewing en gepaardgaande kommunikasiebehoeftes binne die US en die verskillende fakulteite is eiesoortig en vereis pasgemaakte oplossings. Die amptelike taalbeleid van die US is breedweg een van meertaligheid waarbinne vier taalspesifikasies toepassing vind. Hiërargies georden is die vier spesifikasies: Afrikaans (A), Engels (E), tweetalig (T) en parallelmedium (A/E). ${ }^{1}$ Die Taalplan word op modulevlak toegepas en die besluitneming oor die keuse van taalspesifikasie berus by elke fakulteit, soos geformuleer in 'n taalimplementeringsplan deur die fakulteit. Die Fakulteit Regsgeleerdheid het voorgraads die T-opsie as taalspesifikasie. Hierdie opsie behels, wat mondelinge kommunikasie in die klaskamer betref, dat dosente "by benadering in die verhouding 50:50" of "afwisselend" Afrikaans en Engels praat.

In 'n vergelyking van twee taalondersoeke onder studente aan die US (Leibowitz se 2006ondersoek en Schlemmer se 2008-ondersoek) het Marais (2008) die gevolgtrekking gemaak dat die toepassing van die T-opsie verbeter sou kon word deur die instelling van onder andere 'n tolkdiens. Die Raad van die Universiteit het op 13 September 2010 opdrag gegee dat ondersoek gedoen moes word na die effektiewe aanwending van tolking as deel van die taalontwikkelingsplan. 'n Institusionele verslag oor die implementering van tolking in

\footnotetext{
${ }^{1}$ Binne hierdie taalbeleid is die A-opsie die verstekopsie. 'n Nuwe taalbeleid dien tans voor die Raad van die US. Hierdie beleid is een van meertaligheid waarbinne plek gemaak word vir Afrikaans, Engels en isiXhosa.
} 
klaskamers (Universiteit Stellenbosch 2012) is gepubliseer en die Raad van die US het die aanbeveling aanvaar dat tolking as addisionele opsie toegevoeg word tot die taalspesifikasies wat fakulteite kan toepas. Sedert die begin van 2013 is opvoedkundige tolking in verskillende departemente aan die US uitgerol en tans word sowat 113 uit 'n totaal van 1364 voorgraadse modules getolk. ${ }^{2}$

Wanneer die term opvoedkundige tolking (OT) in veral buitelandse tolkteoriebronne gebruik word, word normaalweg verwys na tolking vir gehoorgestremde studente deur middel van gebaretaal (Pöchhacker 2004:14). Simultane (gesproke) opvoedkundige tolking in universiteitsklaskamers het hier te lande in 2005 aan die Noordwes Universiteit (NWU) as afsonderlike subdomein van gemeenskapstolking ontstaan in 'n poging om 'n "nuwe institusionele taalinklusiewe identiteit" te vestig (Verhoef 2010:170). Pöchhacker (2011) verwys na hierdie toepassing van OT as "an extraordinary development in which South Africa leads the spoken-language interpreting world". Om aan die US volledig beslag te kry, wil opvoeders en beleidsmakers weet hoe effektief dit is. Anders gestel: Wat is die waarde van opvoedkundige tolking vir onderrig en leer?

Clausen (2011) het in haar M-tesis die potensiaal van tolking in die Fakulteit Lettere en Sosiale Wetenskappe aan die US ondersoek. Sy maak die volgende opmerking (2011:3): "Oor die lang termyn kan [tolking in klasse] moontlik tot gevolg hê dat meer studente 'n beter begrip sal hê van wat tydens lesings deur dosente gesê word. Dit kan beteken dat dosente of medestudente nie gedurig tydens lesings onderbreek word vanweë kommunikasiesteurnisse nie. Dit sal weer tot beter prestasie lei, en hopelik ook tot 'n hoër slaagsyfer". Die hipoteses het egter buite die bestek van haar studie geval en is nie verder uitgebou of getoets nie. Sy het aan die hand gedoen dat bogenoemde, sowel as die hipotese dat tolking tydsbesparend kan wees, in 'n opvolgstudie nagevors word (2011:103).

Die artikel is gegrond op 'n ondersoek wat die onderwerp was van 'n M-tesis (Brewis 2012). Dit was reeds by die konseptualisering van die studie ooglopend dat die meet van prestasie as metodologie ' $n$ baie ingewikkelde statistiese ontwerp sou verg om die vele veranderlikes wat in die leerporses bestaan, te verreken. So 'n natuurlike eksperiment sou onprakties wees en te groot vir die bestek van die studie. Die studie is daarom gebaseer op die persepsies van die deelnemers aan die leerproses, naamklik studente, dosente en die tolk.

Die ondersoek is gedoen in die Fakulteit Regsgeleerdheid aan die US in 'n proses van Deelnemende Aksienavorsing (DAN) om vas te stel hoe OT teenoor die T-opsie ervaar is en of dit na die mening van die deelnemers die proses van onderrig en leer kon bevorder. Die hipotese van die studie was dat OT volledige moedertaalonderrig in 'n T-opsieklas kan fasiliteer en tot gevolg het dat studente:

- $\quad$ vakinhoud beter verstaan;

- beter met die klaskamersituasie identifiseer ${ }^{3}$; en

- $\quad$ tyd bespaar in die leerproses.

\footnotetext{
${ }^{2}$ Hierdie syfer is verskaf deur die Afdeling Institusionele Navorsing en Beplanning, Augustus 2014.

${ }^{3}$ Vir doeleindes van die studie is die volgende werksdefinisie vir hierdie term aangeneem: 'n gevoel van behoort in die klaskamer; kongruensie tussen die identiteit van die leerder en die klaskameromgewing; toeganklikheid tot die leeromgewing wat legitieme deelname in die sentrum van die leergemeenskap (sien par. 4) ten doel het". Hierdie toestand sou affek en vertroue veronderstel.
} 
Om 'n moontlike verband tussen OT en onderrig en leer te ondersoek, het ek beginsels wat in Akademiese Geletterdheidstudies (AG) geld, verken. Jacobs (2005:476) wys daarop dat akademiese geletterdheid gesitueer is waar taal en leer bymekaarkom: op die raakvlakke tussen taal en vakinhoud. Ek het gefokus op kwessies wat nie op sigself akademiese inhoud het nie, maar wat erken word as fasiliterend in akademiese ontwikkeling, naamlik affek, identiteit, toeganklikheid en deelname. ${ }^{4}$

Hierdie artikel maak, met inagneming van Akademiese Geletterdheidstudies, 'n bydrae tot die oorweging van die rol van tolkgemedieerde kommunikasie in die leerproses. Opvoedkundige tolking word eers as subtipe binne die veld van Tolkstudie geplaas. Daarna volg 'n bespreking van die teorie oor "rol" in Tolkstudie en van idees in Akademiese Geletterdheidstudies. Na 'n kort uiteensetting van die metodologiese keuses wat die tolkproefneming ingelig het, volg 'n bespreking van die resultate. Uiteindelik word aanbevelings gemaak vir die toepassing van opvoedkundige tolking in tersiêre klaskamers aan die US.

\section{Die ontstaan van opvoedkundige tolking as aparte subdissipline in tolkstudie}

In die evolusie van tolking van professionele praktyk tot aparte studieterrein was dit eers konferensietolking en uiteindelik gemeenskapstolking wat teen die middel negentigs erkenning gekry het as aparte akademiese veld. Gemeenskapstolking behels tolking in verskillende velde soos howe, hospitale en ook opvoedkundige gebaretaaltolking (Cokeley 1992, Roy 2000, Harrington 2000 en Napier 2002 in Pöchhacker 2004:37, 163). Simultane gesproke opvoedkundige tolking het vir die eerste keer in 2005 aan die NWU beslag gekry en word sedertdien as vierde taalafleweringsmodus (naas enkel-, dubbel-, en parallelmedium) daar gebruik. ${ }^{5}$ Dit word deur Verhoef en Du Plessis (2008:13) gedefinieer as "simultane tolking deur 'n tolk wat in die klaskamersituasie teenwoordig is". As tolktipologie kan OT as subtipe geplaas word op die kontinuum tussen internasionale omgewings (konferensies) aan die een kant en intrasosiale omgewings (aangesig-tot-aangesig-dialoog) aan die ander. Pöchhacker (in Wadensjö, Dimitrova en Nilsson 2004:12) gee erkenning aan die middelgrond tussen hierdie uiterstes as hy praat van "conference like events in the community". OT is 'n voorbeeld hiervan. Turner (2005:33) sien gebaretaaltolking as 'n hibriede of perifere vorm in die groter landskap van tolktipologie. Verhoef en Blaauw (2009:205) wys daarop dat verskillende onderrigstyle 'n direkte uitwerking het op die tipe tolking wat daarbinne plaasvind en dat by meer formele lesings, die tolktipe meer na konferensietolking neig, terwyl by informele lesings en 'n fasiliterende onderrigstyl, dit meer na gemeenskapstolking neig. Blaauw (2012) meen dat OT in hoofsaak gemeenskapstolking is. Dit verskil in dié opsig daarvan dat dit volgens konferensiestyl in die simultane modus plaasvind. Om uit te werk presies hoe drieledige, veelvlakkige kommunikasie in die opvoedkundige domein uitspeel, is dit nodig om die rol van die tolk te ondersoek.

\section{Rol: Van konferensie tot in die klaskamer}

Uit die metatekste oor "rol" in tolkstudie is dit duidelik dat die rol van 'n tolk vloeibaar is en van situasie tot situasie verskil. Die rol van tolke lê op 'n kontinuum met aan die een kant die

\footnotetext{
${ }^{4}$ Pöchhacker (2011) verwys hierna as die "soft issues" in Opvoedkunde en stel dit as alternatief vir die meet van kognitiewe prestasie. Gile (2011) is eweneens ten gunste van 'n "bottom-up" benadering waar persepsies getoets word en die teorie van Opvoedkunde as vertrekpunt dien om die waarde van tolking vir die leerproses te verken. ${ }^{5}$ Tans word daar in plusminus 1800 periodes per week getolk.
} 
geleibuismodel wat die rol van tolke beskou as neutraal en onsigbaar, en aan die ander kant 'n model wat die tolk beskou as aktiewe deelnemer aan die kommunikasie. Bothma en Verhoef (2008:138) sien tolke aan die NWU as 'n integrale deel van die kommunikasie en tegelyk as vriend, medestudent en dosent. Navorsing in die opvoedkundige domein oor die rol van tolke het aangetoon dat die tolk hoofsaaklik beskou word as 'n fasiliteerder van kommunikasie (Verhoef en Blaauw 2009) en van begrip (Le Roux 2007). Bothma en Verhoef (2008:157) beskryf "fasilitering" as die effektiewe mediasie en balansering van al die funksies van kommunikasie aan die een kant met ekwivalensie tussen bron- en doelteks aan die ander. Dat sulke fasilitering 'n balanseertoertjie is, word veral duidelik as dit kom by die uitvoer van referensiële, fatiese en metalinguistiese funksies van kommunikasie soos woordspel, ironie en humor. Hulle het empiriese bewys gevind daarvoor dat hierdie vermoë van die tolk meer vertroue wek as die mediëring van vakinhoud self. Dit laat studente deel voel van die kommunikasie.

Met verwysing na Niska (2002) se model ${ }^{6}$ het Verhoef en Blaauw (2009:211) gevind dat tolke meestal optree as geleiers van vakinhoud en inligting, maar dat die kommunikatiewe situasie soms vereis dat tolke 'n meer indringende rol speel en onduidelikhede moet opklaar. Olivier (2008:111) doen aan die hand dat bestaande rolmodelle uitgebrei moet word aangesien groter betrokkenheid deur die opvoedkundige tolk 'n sosiaal dinamiese model vereis. Sy het bevestig dat tolke se rol veranderlik is en dat hulle hulself op 'n kontinuum van beweeglikheid bevind. Hulle pas deurgaans by die behoeftes van spesifieke situasies aan. Die meerderheid tolke sien hulleself egter as verduidelikers wat impliseer dat hulle hul taalgebruik aanpas, terme verduidelik en seker maak dat leerders die lesinginhoud verstaan (Olivier 2008:116).

Wat persoonlike eienskappe van opvoedkundige tolke betref en hoe hulle van tolke in ander domeine verskil, het Olivier (2008:99-113) gevind dat opvoedkundige tolke vergeleke met konferensietolke:

- baie meer op voorkennis staatmaak;

- hulle geheue baie meer oefen;

- onder minder druk verkeer en aan minder streng verwagtinge moet voldoen;

- sterker geaffekteer word deur die reaksie van hulle gebruikers; en

- 'n sterk emosionele band het met die rol wat hulle speel as hulp vir die studente.

Sy kom tot die gevolgtrekking dat die verskille wat in haar studie na vore gekom het op die vlak van die tolkproses lê en nie aan die tolke self en hulle vermoëns, kennis en vaardighede toegeskryf kan word nie. Die grootste verskil tussen die tolke in die verskillende domeine lê by hulle siening van hulle rol binne die interaksie.

Gile (2011) is van mening dat dit by opvoedkundige tolking belangrik is om te kyk na spesifieke eienskappe van dosent-student interaksie wat moontlik die interaksie tipeer en moontlik hindernisse kan veroorsaak. Een voorbeeld hiervan noem hy non-egalitarian interaction.

\footnotetext{
${ }^{6}$ Volgens Niska se rolvoorstelling wissel tolke van 'n neutrale posisie (geleibuismodel) na groter betrokkenheid waar hulle uiteindelik selfs 'n voorspraakrol kan aanneem.
} 
In die opvoedkundige tersiêre klaskamer word kommunikasie gekenmerk deur:

- $\quad$ die unieke afstand tussen dosent, student en tolk;

- $\quad$ 'n ongelyke en ongebalanseerde magsverdeling met verskille in status en rol;

- $\quad$ wisselende grade van formaliteit;

- $\quad$ wisselende mate van samewerking; en

- $\quad$ wisseling tussen gedeelde en konflikterende doelwitte. ${ }^{7}$

Navorsing wat gedoen is in situasies wat deur magswanbalanse gekenmerk word, het daarom waardevolle insigte ontsluit. Voorbeelde hiervan is Wadensjö se navorsing in staatsdepartemente in die mediese domein (1992) en immigrasieverhore in polisiekantore (1995). Sy haal Gunnarson (1997) aan wat aantoon dat asimmetrie in die sosiale opstelling die organisasie van die kommunikasie bepaal (1998:282). Ondergeskikte gespreksgenote se deelname is beperk en dominante deelnemers voorsien dikwels nie in die behoeftes van ondergeskiktes nie. Een van die redes hiervoor is volgens Pöllabauer (2004:40) dat deelnemers se basiese linguistiese bronne verskil, sowel as hulle sosio-kulturele en institusionele agtergrondkennis. Angelelli (2004:10) sien die aard van die tolkomgewing as bepalende faktor vir die mate waartoe tolke sigbaar is in die tolksituasie. "Sigbaarheid" kan bevorder of onderdruk word deur die norme van die instansie en kontekstuele faktore soos affek, ouderdom, ras, geslag en sosiale status. In die klaskameromgewing illustreer die struktuur van 'n lesing en spreekbeurte die invloed van hierdie faktore. Turner (2004:181) wys daarop dat sulke faktore deelname en interaksie in die kommunikasie bepaal. Dit het weer 'n uitwerking op die mag en status wat tolke in dié konteks beklee.

Ongelykhede en verskille tussen gespreksgenote verwys ten diepste ook na kulturele verskille en moet deur die tolk in die produk verreken word. Kent (2007:69) sê: "The larger and deepest purpose of simultaneous interpretation is to generate a common culture among people who are maintaining different cultures". Pöchhacker (2008:16) haal Helle Dam aan: "the ideal function of the interpreter is to ensure smooth communication between the primary parties ... to remedy cultural noise on the channel by adjusting the culturally determined peculiarities of the source text'. In 'n bespreking van die belang van kennis van die kulture en die kontekste van studente in die skep van betekenis kom Mantero (2002:3) tot die gevolgtrekking: "Meaning is taken to be contextual." Wanneer kulturele of kontekstuele leidrade deur tolke verduidelik word, is die moontlikheid van misverstande aansienlik minder. Elghezouani (2004:220), in sy bepreking van 'n geskikte rolmodel vir tolke, verkies uiteindelik 'n tolkomgewing wat ruimte laat vir die interaktiewe, kulturele en linguistiese vaardighede van tolke waardeur hulle in staat gestel word om werklik brûe in kommunikasie te wees en volledig as verduidelikers (clarifiers) en tussengangers tussen gespreksdeelnemers op te tree. Hierdie rol is volgens hom die enigste wat asimmetrie in 'n kommunikatiewe situasie kan oorkom.

Wadensjö (1998:237) verduidelik hoe tolke deelneem en 'n rol speel in die skep van betekenis. Sy meen dat tolke vanweë hulle unieke middelposisie "sien" wanneer sprekers op verskillende diskoerstrajekte praat en hoe die proses van betekenisskepping in die situasie ontvou. Sy sê: "Interpreters reflect on talk" (Wadensjö 1998:200). Hierdie funksie van tolke werk wantroue tussen gespreksgenote teë. Nog 'n manier waarop tolke meewerk in betekenisskepping is deur

\footnotetext{
${ }^{7}$ Hierdie parameters is ontleen aan Alexieva (1997:230) se sosio-situasionele opstelling van tolkgemedieerde interaksie.
} 
skakels en verbande tussen konsepte duidelik te maak. Banks, Gray en Fyfe (in Marschark, Sapere, Convertino en Seewagen 2005:67) het in navorsing onder dowe studente gevind dat gebaretaaltolke verwantskappe en afleidings wat nie duidelik deur die dosent genoem word nie vir studente eksplisiet maak. Tolke dui ook diskoersmerkers aan in die kommunikasie. Tebble (2007:201 e.v.) verwys hierna as signposts en framing and focusing moves. 'n Voorbeeld hiervan is wanneer 'n dosent aan die begin van 'n lesing sê: "Goed (framing move) ... laat ons begin (focusing move)". Tebble wys op die belangrikheid daarvan dat tolke hierdie inligting tolk. Indien studente hierdie inligting nie hoor of verstaan nie, word hulle volgens haar benadeel. Wanneer Gambier, Gile en Taylor (1997:33) verduidelik hoe begripvorming plaasvind, wys hulle op die belangrikheid daarvan dat die konteks waarin sekere inligting ontvang word en die makrostruktuur (onderliggende betekenis of intensie) eksplisiet gemaak moet word. Verhoef (2008:164) wys daarop dat opvoedkundige tolke ook van nieverbale en paralinguistiese ${ }^{8}$ elemente gebruik maak in die skep van betekenis. Belangrik hier is die posisie van die tolk in die klaskamer, die stemtoon van die tolk, oogkontak tussen die dosent en die tolk en die spoed en ritme van die getolkte weergawe. Hierdie aspekte verhoog vertroue by studente in die kommunikasie.

\section{Effektiwiteit van OT - 'n Ondersoek na akademiese geletterdheid (AG)}

Die doel van die navorsing was om vas te stel of OT onderrig en leer binne die studiekonteks kan bevorder. Die ondersoek moes daarom plaasvind binne die konteks van 'n universiteitsklaskamer in die Fakulteit Regsgeleerdheid. Taal en taalvaardighede vervul 'n sentrale rol in die regsdissipline. In die teorie en praktyk van Regsgeleerdheid is 'n konvensionele manier van praat en skryf gevestig wat beskryf kan word as ' $n$ besondere sosiale konstruk, of wat Street (2003:78) na verwys as 'n "geletterdheidspraktyk". ${ }^{9}$ Jacobs (2005:476) wys daarop dat akademiese geletterdheid gesitueer is waar taal en leer bymekaarkom: op die raakvlakke tussen taal en vakinhoud. 'n Ondersoek na Akademiese Geletterdheidstudies kon daarom as vertrekpunt dien vir 'n ondersoek na onderrig en leer binne die studiekonteks.

Boughey (2000:281) definieer AG as "knowing how to speak and act in academic discourses". ${ }^{10}$ Sy meen dat mense geletterdheid verwerf deur interaksie met lede van 'n diskoersgemeenskap deur hulle dop te hou totdat die manier van praat, dink, voel en evalueer wat eie is aan die diskoers, vir die waarnemer natuurlik word. Sy sien AG in tersiêre onderwys as die eindpunt van 'n graadkursus en nie as die beginpunt nie. Gee (in Jacobs 2005:478) sien "bevrydende geletterdheid" as die einddoel van AG. Van Schalkwyk (2010:217) bespreek bevrydende geletterdheid na aanleiding van Jacobs (2005) se bespreking en sien dit as daardie oomblik wanneer die student die diskoers van die betrokke dissipline suksesvol binnegedring het en by magte voel om 'n rol binne die diskoers te vervul. So 'n persoon kan nou selfs die diskoers kritiseer en help vorm.

\footnotetext{
${ }^{8}$ Hierdie term verwys volgens Verhoef (2008:165) na kommunikasie wat o.a. woede, affek, sarkasme en verbasing oordra. Aspekte soos stemtoon, spoed en ritme word hierby ingesluit asook nie-intensionele spoedhindernisse soos hoes en keelskoonmaak.

${ }^{9}$ Hy vergelyk dit met Brice Heath se term "literacy event" wat 'n geleentheid is waar teks integraal is tot die interaksie tussen partye en die prosesse van interpretasie (Brice Heath in Street 2003:78).

${ }^{10}$ Gee definieer "diskoers" as: "'n sosiaal-aanvaarde manier van praat, dink, voel, glo, evalueer en van doen waardeur iemand homself laat ken en identifiseer as 'n lid van 'n spesifieke sosiaal-betekenisvolle groepering of netwerk of daardeur kan aandui dat hy 'n sosiaal-betekenisvolle rol kan speel" (in Van Schalkwyk 2010:204).
} 
Wenger (2000:229) gebruik die term praktykgemeenskap ${ }^{11}$ met verwysing na akademiese instellings en leeromgewings. Hy sien leer as 'n sosiale proses wat binne sekere leergemeenskappe deur kulturele gebruike tot uitdrukking kom. Praktykgemeenskappe is die boustene van 'n sosiale leerproses "... and the social containers of the competences that make up such a system". Deelname binne 'n praktykgemeenskap is essensieel vir leer. Hy wys daarop dat die grense wat so 'n gemeenskap omsluit, selde duidelik afgebaken of vasgelê is. Hy verduidelik dat daar aan die rand van 'n gemeenskap gewoonlik 'n tussenin-area (of "periferie") bestaan waar lede wat deel wil word van 'n gemeenskap hulle progressie na die "binnekring" begin. Van Schalkwyk (2010:207) haal Canagarajah (2002) aan wat wys op die belang daarvan dat deelname in die periferie legitiem moet wees. Hiermee bedoel hy dat daar 'n mate van kongruensie tussen die identiteit van die "nuwe" lid en die leergemeenskap moet bestaan en geleenthede geskep moet word vir studente om deel te word van praktyke wat eie is aan die dissipline. Perifere deelname behoort uiteindelik te lei tot binnekennis en die selfvertroue om deelnemers met volle status te word.

Van Schalkwyk (2010:202) haal Walker (2006) aan wat meen dat een van die instaatstellende of verhinderende faktore by die verwerwing van AG die eie identiteit van leerders en studente is. Hulle "linguistiese en kulturele kapitaal" en hoe hulle dit na die leerervaring bring, word uitgelig as 'n deurslaggewende aspek van identiteit in die ontwikkeling van AG. Sy gebruik die terminologie van Lave en Wenger (in Cummins 2006:61) en onderskei tussen "legitieme periferale deelname" en "legitieme sentrale deelname". Die legitimisering van moedertaalgebruik in die klas is volgens haar 'n essensiële komponent van hierdie proses. Cummins (2006:63) wys daarop dat moedertaalkennis 'n wesenlike opvoedkundige komponent van "kulturele kapitaal" is en dat dit essensieel is dat opvoeders 'n milieu skep waar studente se linguistiese en kulturele kapitaal erken, gerespekteer en bevorder word. Dit lei volgens hom uiteindelik tot deep understanding ${ }^{12}$ en die vermoë om kennis uit een konteks na 'n ander oor te dra. Die rede hiervoor is volgens Cummins (1991:77) geleë in die feit dat oordrag van kennis en vaardighede vanaf die moedertaal na ander tale plaasvind. Hy verduidelik in dié verband soos volg: studente leer die konsepte en intellektuele vaardighede wat relevant is vir hulle vermoë om in die dominante taal te funksioneer, in hulle moedertaal. Die oordrag vanaf moedertaal na 'n ander taal beskryf hy as 'n proses waar "nuwe etikette" of "oppervlakstrukture" bloot aan bestaande begrippe of intellektuele vaardighede gekoppel word. Wat oorgedra word, is nie soseer linguistiese elemente nie, maar konseptuele kennis. "It is this conceptual knowledge together with its linguistic manifestations that is being tapped by most verbal academic measures."

By 'n nadere beskouing van Akademiese Geletterdheidstudies was dit duidelik dat konsepte soos affek, identiteit, toeganklikheid en deelname aangetoon word as voorwaardes vir effektiewe onderrig en leer. Hierby inbegrepe is kulturele kapitaal en moedertaalonderrig. Saam het hierdie konsepte struktuur gegee aan die ondersoek tydens die tolkproefneming en uiteindelik waardevolle insigte oor die rol van tolking in onderrig help ontsluit.

\footnotetext{
${ }^{11}$ My vertaling van Wenger (2000) se term "community of practice".

12 Deep understanding (Bransford in Cummins 2006:56) word gedefinieer as: "more than just the ability to remember; deeper levels of understanding are required to transfer knowledge from one context to another. This implies that instruction for deep understanding involves the development of critical literacy (reading between the lines) rather than simply literal comprehension of texts." Hy gebruik hierdie term in samehang met cognitive engagement en is van mening dat dit meer geredelik ontwikkel sal word in 'n konteks waar leer bou op voorkennis en aktiewe deelname in die [akademiese] gemeenskap plaasvind (Cummins 2006:56).
} 


\section{Metodologie}

Die drie vrae wat uit die hipotese geformuleer is en beantwoord moes word, was die volgende:

Kan OT studente help om:

1. die vakinhoud beter te verstaan;

2. beter met die klaskamersituasie te identifiseer; en

3. tyd te bespaar in die leerproses?

Outentieke data moes deur middel van deelnemende aksienavorsing (DAN) ingesamel word om die ervaring van OT in tersiêre klaskamers te ondersoek. DAN toon affiniteite met 'n navorsingsfilosofie wat begrond is in waardes soos demokrasie, gelyke geleenthede en opvoeding in belang van die ontwikkeling van die persoon (Mouton 2001:151 en Reason 1998:2). Data verkry deur aksienavorsing is volgens Reason meer akkuraat omdat dit gegrond is op ervaring, en ook meer eties, omdat dit 'n proses behels van navorsing met mense en nie oor mense nie. Deur 'n bottom-up proses kan navorsers 'n binneperspektief kry op die onderrigkonteks en hoe studente die leerproses ervaar. Die rolspelers, naamlik dosente, studente en die tolk is self deelnemers in die navorsingsproses en kan uiteindelik so eienaarskap neem van die bevindinge.

As navorsingsmetodologie het ek van beide kwantitatiewe en kwalitatiewe metodes gebruik gemaak. Twee modules is vir die proefneming geïdentifiseer naamlik Privaatreg 373 (Deliktereg) en Privaatreg 171 as onderskeidelik groep A en groep B. Groep A (Deliktereg) is vir die proefneming geïdentifiseer omdat twee dubbelperiodes per week vir die module geskeduleer was en die maksimum tolkure in die lig van die tydsbeperkings van die studie beskikbaar gemaak kon word. Dit was ook belangrik om derdejaars by die proefneming te betrek omdat hulle reeds met die navorsingskonteks bekend was en met die T-opsie en die verskillende toepassings daarvan. Hulle sou waarskynlik beter in staat wees om uitdrukking te gee aan aan hul ervaring en om te onderskei tussen taalverwante aspekte en aspekte wat met vakinhoud en die kompleksiteit van die studieveld verband hou. Daar het na my oordeel ook genoeg heterogeniteit te opsigte van taal in die groep bestaan (sien tabel 1).

Tabel 1: Die taalprofiel (huistaal) van die studente in groep A

\begin{tabular}{|l|l|l|l|l|l|}
\hline Afrikaans/Engels & Afrikaans & Engels & Duits & Tsonga & isiXhosa \\
\hline 12 & 117 & 68 & 5 & 1 & 1 \\
\hline
\end{tabular}

Groep B sou as aanvullende kwalitatiewe komponent vir die empiriese proefneming dien. Die waarde hiervan was dat OT getoets kon word in 'n konteks waar die T-opsie moontlik verskillend toegepas word en onder eerstejaars, wat moontlik ander verwagtinge het van onderrig en sieninge van taal.

Drie verskillende metodes van data-insameling is gebruik, naamlik vraelyste, onderhoude en waarneming. Vir groep A is vraelyste uitgedeel met 'n kwantitatiewe (Likert-skaal "geslote" 
vrae) en 'n kwalitatiewe (“oop" vrae) komponent. ${ }^{13}$ 'n Fokusgroepbespreking is gehou met die studente en semigestruktureerde onderhoude met die dosent en die tolk. Die onderhoudvoering verteenwoordig ' $n$ kwalitatiewe komponent. Vir groep B is 'n kort vraelys met hoofsaaklik "oop" vrae uitgedeel wat kwalitatiewe data ingesamel het. 'n Semigestruktureerde onderhoud is met die dosent gehou. Breedweg het die proefneming dus uit twee kwalitatiewe gedeeltes (oop vrae en onderhoude - groep A en groep B) en een kwantitatiewe deel (Likert-skaal vrae groep A) bestaan. Saunders, Lewis en Thornhill (2007:147) meen dat die voordeel van so 'n gemengde metode daarin lê dat dit triangulering ${ }^{14}$ van resultate moontlik maak. Dit maak gevolgtrekkings meer geloofwaardig, omdat die resultate nie aan 'n enkele metode toegeskryf word nie, maar uitkomste is van verskeie perspektiewe wat in dieselfde rigting wys. ${ }^{15}$

Vir die tolking in groep A is 'n ervare tolk gebruik wat oor 'n LLB-graad beskik. Omdat die heersende voorgraadse taalmodel in die Fakulteit Regsgeleerdheid die T-opsie is, is besluit dat die tolk die lesings in die simultane modus sou tolk in twee rigtings, naamlik die Afrikaanse inhoud in Engels en die Engelse inhoud in Afrikaans. 'n Totaal van 12 lesings van 50 minute elk is getolk. Tolking het deur middel van die draagbare Sennheiser-toergidsstelsel plaasvind. Die aanvanklike doel was om 40 vrywilligers uit die klas te werf om aan die proefneming deel te neem, waarvan die groep min of meer 'n gelyke verdeling tussen Engelse en Afrikaanse studente moes wees. Uiteindelik het 'n totaal van 39 studente as vrywilligers aangemeld om van die tolking gebruik te maak.

Vir die tolking in groep B het die navorser, wat ook oor 'n LLB-kwalifikasie beskik, die tolking waargeneem. Dertien studente is geïdentifiseer wat van die tolking gebruik sou maak. Hulle was almal studente wat probleme het om Afrikaans in klasse te verstaan. Slegs die Afrikaanse inhoud is in Engels getolk. 'n Totaal van sewe lesings van 50 minute elk is getolk.

Twee aparte vraelyste is gebruik, naamlik 'n vraelys vir gebruikers en een vir nie-gebruikers van die tolkdiens. Beide vraelyste het bestaan uit drie afdelings, naamlik biografiese inligting (Afdeling A), die T-opsie (Afdeling B) en OT (Afdeling C). Die vrae vir die eerste twee afdelings is identies, terwyl die vrae in Afdeling $\mathrm{C}$ verskil met betrekking tot die ervaring van tolking. Die nie-gebruikers moes kommentaar lewer oor of hulle die tolking steurend gevind het en oor die nodigheid en die lewensvatbaarheid van OT in hulle fakulteit. Die vraelyste bevat beide "oop" en "geslote", Likert-skaal, vrae. Die onderlinge vrae hou telkens verband met die drie vrae wat uit die hipotese geformuleer is (sien par. 5 hierbo). Begripvorming, identifisering met die leerkonteks, tydbestuur en "affek", naamlik hoe die respondent emotief staan teenoor die T-opsie en OT onderskeidelik, is getoets. Die invloed van die T-opsie en tolking onderskeidelik op die neem van aantekeninge is ook getoets sowel as die vertroue wat respondente in die tolk en OT het.

\footnotetext{
${ }^{13}$ Omdat die T-opsie as verstektaalopsie binne die studiekonteks geld, is die vraelyste so opgestel dat die studente se ervaring telkens eers van die T-opsie en dan van die tolking, getoets is. Aspekte wat met die hipotese van die studie en konsepte uit AG (sien par. 4) verband hou, is vir beide die taalopsies in parallelle formaat getoets.

${ }^{14}$ Berg (2009:5) verduidelik hierdie begrip soos volg: "Methods impose certain perspectives on reality. Every method is a different line of sight directed at the same point, observing social and symbolic reality. By combining several lines of sight, researchers obtain a better, more substantive picture of reality. The use of multiple lines of sight is called triangulation."

${ }^{15}$ Saunders et al. (2007:147) verwys hierna as die metode-effek.
} 
Deur die vraelys vooraf in die klas te verduidelik en deur die sorgvuldige bewoording van elke vraag, het ek probeer verseker dat die respondente telkens net een afleiding daaruit sou maak. Vir die geldigheid van die data was dit belangrik om tot die kennis en ervaring van die respondente deur te dring sodat ondubbelsinnige verbande tussen die data en die resultaat afgelei kon word. Deur konsekwente navorsingstegnieke en 'n deursigtige proses het ek probeer om betroubare resultate te verseker.

\section{Resultate}

\subsection{Kwantitatiewe resultate ${ }^{16}$ - Groep A}

\subsubsection{Verskil in taalvaardigheid tussen eerste en tweede tale}

Hoe groot is die verskil in jou akademiese taalvaardigheid tussen jou eerste en tweede taal? (Vraag 1.3)

Vir groep A is 137 vraelyste uiteindelik voltooi, waarvan 36 gebruikers en 101 nie-gebruikers van die tolkdiens was. Uit die hele groep van 137 respondente was $12 \%(n=17)$ van mening dat daar 'n uiters groot verskil in hulle akademiese taalvaardigheid tussen hulle eerste en tweede tale is. Vyf en dertig persent (35\%) $(n=48)$ het gemeen dat daar 'n "redelike verskil" is, $45 \%$ $(\mathrm{n}=61)$ het gevoel daar is "min verskil" en $8 \%(\mathrm{n}=11)$ dat daar "geen verskil" is nie. Belangrik hier is dat ' $n$ analise van variansie getoon het dat Engels eerstetaalsprekers 'n statisties beduidend ${ }^{17}$ groter verskil in hulle taalvaardigheid tussen eerste en tweede taal ervaar het as Afrikaans eerstetaalsprekers $(p<0.01)$ (sien vraag 1.3, tabel 3). Die gebruikers van die tolkdiens het ' $n$ beduidend groter verskil aangedui as die nie-gebruikers $(\mathrm{p}=0.04)$ (sien vraag 1.3 , tabel 2).

\subsubsection{T-opsie}

Hoe ervaar jy die T-opsie (Vraag 2.1)

Uit die totale groep het $9 \%(\mathrm{n}=12)$ die T-opsie as "baie positief" ervaar. Ses en sestig persent $(n=88)$ was positief daaroor, $20 \%(n=27)$ was negatief en $5 \%(n=6)$ het dit as "baie negatief" ervaar. As die gebruikers van die tolkdiens afsonderlik ontleed word, is dit statisties beduidend dat Engelse gebruikers meer negatief is oor die T-opsie as Afrikaanse gebruikers $(p<0.01)$.

Gaan daar na jou mening tyd verlore as gevolg van die T-opsie?(Vraag 2.2)

Uit die hele groep van 137 respondente het $4 \%(n=6)$ aangedui dat "uiters baie" tyd as gevolg hiervan verlore gaan, $32 \%(n=44)$ het gevoel "redelik baie" tyd gaan verlore, $49 \%(n=67)$ het gevoel "redelik min" tyd gaan verlore en $15 \%(n=20)$ studente het aangedui dat "geen" tyd na

\footnotetext{
${ }^{16}$ Die resultate van groep B sal bespreek word onder kwalitatiewe resultate, omdat die vraelyste vir dié groep slegs "oop", kwalitatiewe vrae bevat het.

${ }^{17}$ Hipotesetoetse is gedoen waar die groepe vergelyk is om te bepaal of hulle die vrae dieselfde beantwoord het. Die nulhipotese is dus dat die vrae dieselfde beantwoord is. Die $p$-waarde dui aan of die nulhipotese anvaar of verwerp moet word. 'n Universele betekenispeil van 5\% is gebruik wat beteken dat indien die $p$-waarde kleiner as 0.05 is, die kans baie klein is dat die nulhipotese waar is. Dan word die nulhipotese verwerp en dit beteken dat die twee groepe die vraag verskillend beantwoord het. Die p-waardes word telkens aangedui as betekenisvol op die $1 \%$-, die $5 \%$ - of die $10 \%$-peil.
} 
hulle mening verlore gaan nie. Ses en dertig persent $(36 \%)(n=50)$ van die groep is dus van mening dat "redelik baie" tot "uiters baie" tyd verlore gaan as gevolg van die T-opsie. ${ }^{18}$

Is dit maklik of moeilik om aantekeninge in 'n tweetalige klas te maak?(Vraag 2.3)

Uit die hele groep van 137 respondente het $3 \%(n=4)$ aangedui dat dit "baie moeilik" is, $23 \%$ $(\mathrm{n}=31)$ het gesê "moeilik", 59\% $(\mathrm{n}=59)$ het dit as "maklik" beskryf en 15\% $(\mathrm{n}=20)$ as "baie maklik". Vir 26\% (n=35) is dit dus "moeilik" of "baie moeilik" om aantekeninge in 'n tweetalige klas te maak. Gebruikers van die tolkdiens het dit betekenisvol moeiliker gevind as nie-gebruikers $(p<0.01)$ (sien vraag 2.3, tabel 2). Verskille tussen gebruikers en nie-gebruikers het slegs in die Engelse groep voorgekom $(p<0.01)$. Die Engelse gebruikers vind dit dus beduidend moeiliker om aantekeninge in 'n tweetalige klas te maak as die ander groepe $(\mathrm{p}=0.09)$.

Ervaar jy probleme om dosente te verstaan as gevolg van taalgebruik in die klas?(Vraag2.4) Uit die hele groep van 137 respondente het 4\% $(n=5)$ "dikwels" aangedui, 36\% (n=49) "somtyds", 34\% $(\mathrm{n}=46)$ "selde" en $27 \%(\mathrm{n}=37)$ "nooit". Veertig persent $(40 \%)(\mathrm{n}=54)$ van die totale groep respondente het dus aangedui dat hulle probleme ondervind om die dosent te verstaan as gevolg van taal. Statistiese analises het aangedui dat Engelse studente beduidend meer as Afrikaanse studente $(p<0.01)$ (sien vraag 2.4 , tabel 3 ) en gebruikers ook groter $(p=0.04)$ probleme as die nie-gebruikers het daarmee om die dosent te verstaan as gevolg van taalgebruik in die klaskamer (sien vraag 2.4, tabel 2). As die gebruikers apart ontleed word, sukkel Engelse gebruikers beduidend meer hiermee as die Afrikaanse gebruikers $(p=<0.01)$.

Voel jy ooit uitgesluit as dit kom by taal in die klaskamer?(Vraag2.5)

Uit die hele groep van 137 respondente het 5\% $(n=7)$ aangedui dat hulle "dikwels" uitgesluit voel, $18 \%(n=24)$ het gesê dat hulle "somtyds" so voel, $34 \%(n=46)$ het gesê "selde" en $44 \%$ $(n=60)$ het gesê "nooit". Dit is interessant dat onder die nie-gebruikers van die tolkdiens, $18 \%$ $(\mathrm{n}=18)$ aangedui het dat hulle soms uitgesluit voel weens taalgebruik in die klas. Engelse respondente voel betekenisvol meer uitgesluit as Afrikaanse respondente $(\mathrm{p}<0.01)$ (sien vraag 2.5, tabel 3). 'n Analise van variansie het getoon dat die Engelse gebruikers die groep is wat betekenisvol meer as die ander groepe 'n gevoel van uitsluiting ervaar i.v.m. taal in die klaskamer $(\mathrm{p}<0.01)$.

Is daar soms inligting soos woordspelings (ironie, sarkasme), sydelingse opmerkings of grappe wat jy nie verstaan nie a.g.v. taalgebruik in die klas?(Vraag 2.6)

Uit die hele groep van 137 respondente het $5 \%(n=7)$ aangedui dat hulle dikwels nie verstaan nie, 17\% (n=23) "somtyds", 29\% (n=40) "selde" en 49\% $(n=67)$ "nooit". Statistiese analises het aangedui dat Engelse gebruikers betekenisvol meer as Afrikaanse gebruikers daarmee sukkel $(\mathrm{p}<0.01)$. Engelse respondente het beduidend groter probleme daarmee as Afrikaanse respondente $(\mathrm{p}<0.01)$ om paralinguistiese aspekte in die klas te verstaan (sien vraag 2.6, tabel $3)$.

Voel jy dat Afrikaans en Engels gelykwaardig in die klaskamer behandel word?(Vraag 2.7)

Uit die hele groep van 137 respondente het 7\% (n=9) gesê "nee nooit nie", 20\% (n=27) "selde", $64 \%(n=87)$ "meestal" en $10 \%(n=14)$ "ja altyd". As gekyk word na die rapportering van vraag 2.6 in tabel 2 en 3 is daar geen betekenisvolle verskille tussen gebruikers en nie-gebruikers of

\footnotetext{
${ }^{18}$ Hierdie vraag het ook ' $\mathrm{n}$ kwalitatiewe gedeelte bevat. Redes vir response word uiteengesit en bespreek in par. 6.2.1.
} 
tussen Afrikaanse en Engelse gebruikers m.b.t. vraag 2.6 nie. Statistiese analises van die totale groep het egter aangedui dat Engelse studente statisties beduidend sterker as Afrikaanse studente gevoel het dat die twee onderrigtale nie gelykwaardig in klasse behandel word nie $(\mathrm{p}=0.03)$.

Uit die statistiese data blyk dit dat die Engelse gebruikers van die tolkdiens die groep was waar die grootste verskille in akademiese taalvaardigheid tussen die twee onderrigtale ervaar word. Dis ook hierdie groep wat betekenisvol meer negatief oor die T-opsie is as die ander groepe. Hulle voel betekenisvol meer uitgesluit op grond van taalgebruik in klasse en het ook groter probleme as die ander studente om vakinhoud sowel as paralinguistiese aspekte tydens lesings te verstaan. Die afneem van aantekeninge is ook vir hulle betekenisvol moeiliker as vir die ander groepe.

Tabel 2: Vergelyking van antwoorde tussen tolkgebruikers en nie-gebruikers. Gemiddelde tellings (standaardafwyking) word gerapporteer.

\begin{tabular}{|l|l|l|l|}
\hline Vraag & Tolk gebruikers & Tolk nie-gebruikers & $\mathrm{p}$-waarde \\
\hline 1.3 & $2.1(0.87)$ & $2.6(0.75)$ & $\mathrm{p}=0.04$ \\
\hline 2.1 & $2.7(0.73)$ & $2.8(0.59)$ & $\mathrm{p}=0.28$ \\
\hline 2.2 & $2.7(0.74)$ & $2.7(0.76)$ & $\mathrm{p}=0.28$ \\
\hline 2.3 & $2.6(0.62)$ & $2.9(0.67)$ & $\mathrm{p}<0.01$ \\
\hline 2.4 & $2.5(0.91)$ & $2.9(0.79)$ & $\mathrm{p}=0.04$ \\
\hline 2.5 & $2.8(0.99)$ & $3.2(0.80)$ & $\mathrm{p}=0.06$ \\
\hline 2.6 & $2.8(1.06)$ & $3.4(0.78)$ & $\mathrm{p}=0.04$ \\
\hline 2.7 & $2.6(0.79)$ & $2.8(0.630$ & $\mathrm{p}=0.12$ \\
\hline
\end{tabular}

Tabel 3: Vergelyking van antwoorde tussen Afrikaanse en Engelse respondente. Gemiddelde tellings (standaardafwyking) word gerapporteer.

\begin{tabular}{|l|l|l|l|}
\hline Vraag & Afrikaanse respondente & Engelse respondente & $\mathrm{p}$-waarde \\
\hline 1.3 & $2.6(0.74)$ & $2.1(0.81)$ & $\mathrm{p}<0.01$ \\
\hline 2.1 & $2.8(0.62)$ & $2.7(0.76)$ & $\mathrm{p}=0.09$ \\
\hline 2.2 & $2.6(0.75)$ & $2.9(0.72)$ & $\mathrm{p}=0.09$ \\
\hline 2.3 & $2.9(0.62)$ & $2.6(0.77)$ & $\mathrm{p}=0.04$ \\
\hline 2.4 & $3.0(0,82)$ & $2.4(0.75)$ & $\mathrm{p}<0.01$ \\
\hline 2.5 & $3.3(0.75)$ & $2.7(0.97)$ & $\mathrm{p}<0.01$ \\
\hline 2.6 & $3.5(0.67)$ & $2.6(1.02)$ & $\mathrm{p}<0.01$ \\
\hline 2.7 & $2.9(0.64)$ & $2.6(0.74)$ & $\mathrm{p}=0.03$ \\
\hline
\end{tabular}

\subsubsection{Opvoedkundige tolking}

Hoe het jy klaskamertolking ervaar? (Vraag3.1)

Drie en tagtig persent $(83 \%)(\mathrm{n}=29)$ van die respondente wat van die tolkdiens gebruik gemaak het, het dit as "baie positief" en "positief" ervaar. Sewentien persent $(17 \%)(n=6)$ het aangedui dat hulle dit "negatief" en "baie negatief" ervaar het.

Het tolking jou gehelp om die lesing beter te verstaan?(Vraag 3.2)

Sewe en sestig persent $(67 \%)(n=24)$ het die lesing "waarskynlik" of "definitief" beter verstaan as gevolg van die tolkdiens terwyl $25 \%(\mathrm{n}=9)$ nie so gedink het nie en $8 \%(\mathrm{n}=3)$ die lesing "glad nie" beter verstaan het as gevolg van die tolking nie. 
Het jy meer tuis in die klaskamer gevoel as gevolg van die tolkdiens?(Vraag 3.3)

Drie en vyftig persent (53\%) ( $\mathrm{n}=19)$ voel nou "waarskynlik" en "definitief" meer tuis in die klaskamer terwyl 33\% (n=12) nie gedink het dat tolking hulle meer tuis in klasse laat voel het nie. Veertien persent $(14 \%)(n=5)$ het glad nie meer tuis in klasse gevoel as gevolg van tolking nie.

Watter invloed het tolking gehad op hoe jy aantekeninge tydens 'n lesing maak? (Vraag 3.4) Ses en vyftig persent $(56 \%)(n=20)$ was van mening dat die tolkdiens die maak van aantekeninge nou "effens" en "baie" vergemaklik het. Veertien persent $(14 \%)(n=5)$ was neutraal hieroor. Agt en twintig persent $(28 \%)(n=10)$ het gemeen dat tolking die neem van aantekeninge "effens" bemoeilik het en $3 \%(n=1)$ dat tolking die neem van aantekeninge nou "baie" bemoeilik het.

Het die tolk na jou mening 'n getroue weergawe gegee van dit wat die dosent gesê het, m.a.w. is vakterminologie en vakinhoud korek oorgedra?(Vraag 3.5)

Op hierdie vraag het slegs $3 \%(\mathrm{n}=1)$ gesê: "ek dink nie so nie". Sewe en veertig persent $(47 \%)$ $(n=17)$ het gesê: "ja, ek dink so" en 50\% $(n=18)$ het gesê: "definitief". Hierdie vraag het die grootste positiewe resultaat getoon. Hoewel die twee talgroepe binne die gebruikersgroep wesenlik verskil het ten opsigte van verskeie aspekte soos hieronder gerapporteer, is dit betekenisvol dat daar nie 'n beduidende verskil is in hulle siening van die gehalte van die tolk en die vertroue wat hulle in die tolk gestel het nie $(\mathrm{p}=0.33)$.

Watter invloed het tolking gehad op jou tydsbestuur m.b.t. leer - beide in en buite die klaskamer?(Vraag 3.9)

Agt en veertig persent (48\%) $(n=16)$ het aangedui dat hulle 'n "positiewe" of "baie positiewe" verskil ervaar. Agt en veertig persent $(48 \%)(n=16)$ was neutraal hieroor en $3 \%(n=1)$ het 'n negatiewe uitwerking ervaar. Statistiese analises het nie 'n beduidende verskil aangedui tussen Engelse en Afrikaanse respondente se ervaring van die uitwerking van tolking op tydsbestuur nie $(p=0.13)$.

Indien tolking ingestel word, sal jy daarvan gebruik maak?(Vraag 3.8)

Op hierdie vraag het 42\% (n=15) gesê: "definitief", 39\% $(n=14)$ het gesê: "ja, waarskynlik", $17 \%(n=6)$ : "ek dink nie so nie" en $3 \%(n=1)$ sal dit "definitief" nie gebruik nie. Die Engelse gebruikers het 'n statisties beduidend sterker moontlikheid aangedui dat hulle "waarskynlik" of "definitief" in die toekoms van die tolkdiens gebruik sal maak $(\mathrm{p}<0.01)$.

Onder die gebruikers van die tolkdiens is die resultate statisties beduidend dat Engelse gebruikers:

- meer positief is oor die tolkdiens as die Afrikaanse gebruikers ( $\mathrm{p}=0.01)$;

- beter verstaan as gevolg van tolking in vergelyking met Afrikaanse gebruikers $(\mathrm{p}<0.01)$

- meer tuis voel as gevolg van die tolkdiens in vergelyking met Afrikaanse gebruikers $(\mathrm{p}=0.01)$;

- beter aantekeninge maak as gevolg van tolking in vergelyking met Afrikaanse gebruikers $(\mathrm{p}<0.01)$; en

- eerder van die tolkdiens sal gebruik maak as die Afrikaanse studente, sou die diens ingestel word $(\mathrm{p}<0.01)$. 
Onder die nie-gebruikers van die tolkdiens het $1 \%(\mathrm{n}=1)$ aangedui dat hulle dit "uiters steurend" vind en 4\% (n=4) dat hulle dit "tot 'n mate" steurend gevind het. Vir die res was dit "nie eintlik steurend nie" $(33 \%)(n=33)$ en "glad nie" $(62 \%)(n=63)$ steurend nie. Drie en negentig persent $(93 \%) \quad(n=128)$ uit die totale groep (gebruikers en nie-gebruikers) het tolking as 'n lewensvatbare opsie beskou om diverse taalbehoeftes in die Fakulteit Regsgeleerdheid aan te spreek. Nege en sewentig persent $(79 \%)(n=108)$ van die totale groep was van mening dat opvoedkundige tolking nodig is in die Fakulteit Regsgeleerdheid.

Uit die korrelasies ${ }^{19}$ in tabel 4 kan die volgende afleidings gemaak word:

- Hoe swakker respondente se begrip in die T-opsieklas was, hoe beter was hulle begrip in tolkgemedieerde klasse $(\mathrm{r}=-0.56)$.

- Hoe minder tuis hulle in die T-opsieklas voel, hoe meer tuis voel hulle in die getolkte klasse $(\mathrm{r}=-0.49$.

- Hoe moeiliker dit vir hulle was om aantekeninge in 'n T-opsieklas te maak, hoe makliker is dit vir hulle om aantekeninge in getolkte klasse te maak $(\mathrm{r}=-0.61)$.

- Hoe groter hulle persepsie van die verskil in hulle taalvaardigheid was, hoe positiewer het hulle die tolking ervaar $(\mathrm{r}=-0.39)$, hoe meer het hulle in die getolkte klasse tuis gevoel $(\mathrm{r}=-0.45)$, hoe makliker was dit om aantekeninge in 'n getolkte lesing te maak $(\mathrm{r}=-0.41)$, hoe nodiger sien hulle tolking $(\mathrm{r}=-0.46)$, hoe groter is die waarskynlikheid dat hulle dit sal gebruik $(\mathrm{r}=-0.45)$ en hoe groter was respondente se vertroue in die gehalte van die tolking $(\mathrm{r}=-0.46){ }^{20}$

Tabel 4: Korrelasies tussen resultate

\begin{tabular}{|c|c|c|c|c|c|}
\hline Vraag & Vraag & $\begin{array}{l}\text { Spearman } \\
\text { korrelasie }\end{array}$ & $\begin{array}{l}\text { Spearman } \\
\text { p-waarde }\end{array}$ & Pos. & Neg. \\
\hline 2.4: Verstaan in T-opsie & 3.2: Verstaan in tolking & -0.56 & $<0.01$ & & $\mathrm{x}$ \\
\hline 2.5: Tuisvoel in T-opsie & 3.3: Tuisvoel in tolking & -0.49 & $<0.01$ & & $\mathrm{x}$ \\
\hline 2.3: Aantekeninge in T-opsie & 3.4: Aantekeninge in T-opsie & -0.61 & $<0.01$ & & $\mathrm{X}$ \\
\hline 1.3: Verskil in taalvaardigheid & 3.2: Verstaan in tolking & -0.30 & 0.07 & & $\mathrm{x}$ \\
\hline 1.3: Verskil in taalvaardigheid & 3.7: Nodigheid van tolking & -0.46 & $<0.01$ & & $\mathrm{x}$ \\
\hline 1.3: Verskil in taalvaardigheid & 3.1: Affek in tolking & -0.39 & 0.02 & & $\mathrm{x}$ \\
\hline 1.3: Verskil in taalvaardigheid & 3.3: Tuisvoel in tolking & -0.45 & $<0.01$ & & $\mathrm{X}$ \\
\hline 1.3: Verskil in taalvaardigheid & 3.4: Aantekeninge in tolking & -0.41 & $<0.01$ & & $\mathrm{x}$ \\
\hline 1.3: Verskil in taalvaardigheid & 3.5: Vertroue in tolk & -0.46 & $<0.01$ & & $\mathrm{x}$ \\
\hline 1.3: Verskil in taalvaardigheid & 3.6: Lewensvatbaar & 0.01 & 0.94 & $\mathrm{x}$ & \\
\hline 1.3: Verskil in taalvaardigheid & 3.8: Sal u tolking gebruik & -0.45 & $<0.01$ & & $\mathrm{x}$ \\
\hline 1.3: Verskil in taalvaardigheid & 3.9: Tydsbestuur in tolking & 0.10 & 0.59 & $\mathrm{x}$ & \\
\hline
\end{tabular}

\footnotetext{
${ }^{19}$ Statistiese korrelasies het beduidende verbande tussen vrae aangedui en word bespreek n.a.v. die sg. Spearmankorrelasie. 'n Positiewe korrelasie beteken dat hoe hoër 'n respondent op een vraag geantwoord het, hoe hoër het hy/sy op die ander vraag geantwoord en 'n negatiewe korrelasie dui op die teenoorgestelde.

${ }^{20}$ Die teenoorgestelde is vir al hierdie afleidings ook waar.
} 


\subsection{Kwalitatiewe resultate}

\subsubsection{Vraelyste}

\subsubsection{T-opsie}

Die mees algemene uitgangspunt in groep A was dat die T-opsie ekstra tyd in beslag neem. Frases soos "vanselfsprekend word tyd gemors", "inligting word onnodig herhaal", "ons kry net 'n gedeelte uit die waarde van 'n lesing" en "tyd kan beter aangewend word", kom algemeen voor. Een respondent merk op: “. .. inligting word soms tot vier maal herhaal”. Nog een sê : "Dieselfde goed word nie herhaal nie. Jy voel gedurig jy mis uit."

Die tweede mees algemene siening was dat die herhaling dit moontlik maak om inligting in jou moedertaal te hoor, dat dit lei tot groter begrip, omdat jy inligting meer as een maal hoor en dat dit nuttig is. Respondente het gekwalifiseer dat dit slegs die geval is as jy altwee tale verstaan en daar nie 'n groot verskil in akademiese taalvaardighede tussen jou eerste en tweede taal is nie.

Sommige respondente het gesê dat die herhaling hulle konsentrasie verbreek. "Sometimes the lecturer rants off in one language and loses the attention of the other learners." Ander het gemeen dat die herhaling minder tyd toelaat vir die verduideliking van konsepte: "More information can be shared without having to change languages particularly in an academically dense subject such as law where time is already limited."

Uit groep B het drie respondente aangedui dat hulle die T-opsie positief ervaar terwyl een 'n negatiewe ervaring aangedui het. Een respondent het beide "positief" en "negatief" gemerk. Die positiewe reponse het verwys na die feit dat dit beide groepe akkommodeer en dat tweetalige studente daarby baat kan vind. Die negatiewe reponse is in een geval as volg gemotiveer: "It becomes hard to focus one's concentration when the lecturer is constantly switching from one language to the other. In a T-option class when a lecturer speaks in one language and then follows on from the previous sentence in the other language it becomes a lot harder as there are entire sentences which become unknowable as they are not translated."

\subsubsection{Tolking}

Tydens die lesings het die tolking respondente in staat gestel om "by te hou". Hulle het verstaan en kon vinniger skryf omdat hulle nie die woorde van die dosent telkens eers moes vertaal en dan neerskryf nie. "You spend less time trying to understand the work and you spend more time learning." "It was a pleasure to be able to study extensively in English."

Minder vertaalwerk van klasaantekeninge moes tydens selfstudie gedoen word. Aantekeninge was nou vollediger. Minder tyd is aan selfstudie bestee omdat dit minder nodig was om inligting uit handboeke in aantekeninge te inkorporeer of dit in handboeke na te gaan. Begrip tydens selfstudie was ook beter as gevolg van beter begrip in die klasse. Dit het tyd bespaar. "It cuts out a lot of time spent trying to self-study/understand the work that was discussed solely in Afrikaans in class. Inside the classroom it promoted understanding. It was a very useful tool". 
Klasaantekeninge wat studente self gemaak het, was meer omvattend - volgens een respondent tot $50 \%$ meer. Aantekeninge was nou meer bruikbaar en meer verstaanbaar.

Tolking het die leerproses verbeter. " ...before I would often "zone out" during the Afrikaans part of the lecture, but now I could understand a lot more of the lecture which enhanced the effectiveness of my learning process".

Tolking het een student beter met die klas laat identifiseer. "It was very worthwhile to understand the Afrikaans instructions. It made me feel more part of the class as all the Afrikaans was translated including ... questions and answer".

\subsubsection{Fokusgroepbespreking}

Uit die fokusgroepbespreking is die response uit die vraelyste verder ondersoek en bevestig. Hier volg enkele opmerkings: ${ }^{21}$

\subsubsection{Kontekstualisering van inligting}

- Dit is nou met die tolking baie makliker om in die klas te volg wat die dosent sê. Wat gewoonlik gebeur is dat hy 'n onderwerp inlei en dan oorskakel na Engels. Die student weet dan nie wat aangaan nie. Nou, met behulp van die tolk, kon ek volg toe die onderwerp ingelei is en verstaan ek die konsep in geheel. Dit is nou makliker om te weet wat aangaan.

\subsubsection{Organisatoriese gesprekvoering}

- Ek tel dikwels nie die organisatoriese gesprekvoering op nie. Die dosent praat byvoorbeeld oor toetse of sake wat ons moet lees. "I never ever hear this ...like stupid things: where we're writing tests". Dit veroorsaak ekstra stres.

\subsubsection{Aantekeninge}

- Omdat jy beter verstaan is jou aantekeninge langer... as jy dit vergelyk met hoe lank dit voorheen was. My aantekeninge het altyd so drie bladsye beslaan en nou beslaan dit ses bladsye.

\subsubsection{Taalverwerwing}

- I don't sit in a class to learn Afrikaans. I sit here to get the lecture down. I just want to hear what he is trying to say. I don't use the T-option to learn Afrikaans.

- I know that many people will try to argue that I should try to listen to the Afrikaans to improve mine but it is hard to improve your Afrikaans when she is using Afrikaans legal jargon as opposed to basic Afrikaans.

\footnotetext{
${ }^{21}$ Die inhoud van opmerkings is deur die skrywer vertaal. Sekere betekenisvolle opmerkings word direk uit die Engels aangehaal.
} 
- Ek gebruik dit wel om die ander taal aan te leer. Ek hou van die T-opsie omdat dit my Afrikaans help. My Afrikaans het beter geraak vandat ek op Stellenbosch is. Ek verkies egter om die hele klas in Engels te hê, want ek leer makliker in Engels.

Die oorheersende gevoel tydens die fokusgroepbespreking was dat sommige studente in die Topsieklasse sukkel en dat hulle gefrustreerd is dat maatreëls nie in plek gestel word wat hulle kan akkommodeer en die leerproses vir hulle vergemaklik nie.

- Last year I struggled and it has affected me. Sometimes I don't want to attend a lecture because I feel ... and you know it's unfair to have to sit next to this guy (wys na persoon langs hom) and he has to open up his notes for me so that I can copy.

- Some lecturers entirely do the whole translation thing and some do the English and then you hope they'll get back to the English and then he never does and I have to fill him in (vorige student) so that he doesn't have gaps ... when you get back to the English its not on the point where he left off ... its hard.

- I cannot speak a word of Afrikaans and I chose to come to this university because I want to be here ... afterwards you learn that there are other alternative methods to help and foster studying in English ... so if this is available then why don't they give everyone an equal opportunity to learn in his/her own language?

Een respondent het aangedui dat die tolking negatiewe implikasies op sy/haar tydsbestuur in die klasse gehad het vanweë die oorskakeling tussen die twee tale en die nodigheid om die oorstuk telkens af te haal en op te sit. "It was irritating, confusing and distracting." Vyf respondente het negatiewe opmerkings gemaak oor tolking wat met hierdie aspek verband hou. Hierdie opmerkings kom uit die groep van Afrikaanssprekende studente wat beide onderrigtale verstaan. Hulle algemene gevoel was dat die tolking nie vir hulle van nut is nie.

\subsubsection{Onderhoude met dosente}

Uit die onderhoude met die dosente het die frustrasie wat hulle met taal in T-opsieklasse ervaar, duidelik na vore gekom. Die vertaalfunksie bring ekstra werk mee. Tyd gaan in klasse verlore as gevolg hiervan (tussen $30 \%$ en $50 \%$ ). Dosent A voel dat die konstante herhaling sy gedagtegang onderbreek en dat hy momentum verloor. Hy voel dat die werk beter en in meer diepte verduidelik kon word as hy in sy moedertaal kon klasgee. Hy ervaar dat studente nie binne die T-opsie na vore kom en in klasse aandui wanneer hulle nie verstaan nie. Swak begrip het ' $n$ negatiewe uitwerking op die mate van interaksie in klasse. Dosent B voel kognitief onder druk en dit bring frustrasie mee. Wanneer studente handopsteek hoop sy telkens hulle gaan vrae vra oor inhoud. Dit bly egter: "Ma'am, can you please repeat that in English". Interaksie in klasse is baie laag, die fokus bly op taalkwessies en leer bly op die oppervlak.

Die reaksie van die dosente op die tolking was uit die staanspoor oorweldigend positief. Op 'n vraag of die tolking hom in enige opsig gepla het, was dosent A se antwoord soos volg: "Glad nie. Ek het gedink dit gaan my pla, maar glad nie. Ek het gedink dit gaan my aandag aftrek en die studente se konsentrasievermoë verlaag, omdat hulle nie gaan konsentreer op wat die dosent sê nie. Ek het gedink dat hulle heeltyd na die tolke sou kyk, maar dit was glad nie die geval 
nie." Dosent B het die tolking "geweldig positief" ervaar. Sy was nie van die tolk bewus in die klas nie en het die tolking in geen opsig steurend gevind nie.

Op 'n vraag of hy vertroue in die tolking gehad het en of die tolk die korrekte inligting aan die studente oordra, het dosent A positief geantwoord. Hy baseer dit op die voorbereidingsmateriaal wat hy aan die tolk beskikbaar gestel het. Hy was bewus van haar ervaring in die regsveld en haar regskwalifikasies. Hy het 'n gemaklike verhouding met haar gehad en het telkens tussen periodes by haar seker gemaak dat hy stadig en duidelik genoeg gepraat het. Hy het haar telkens voorberei op wat hy volgende sou behandel. Hyself het meer gerus in klasse gevoel, want hy het besef dat die studente beter verstaan. Hulle het ook gesê dat hulle steeds sy stem kon hoor terwyl hulle na die tolk geluister het.

\subsubsection{Waarneming}

Uit die waarneming was dit duidelik dat die twee dosente se toepassing van die T-opsie verskil. Dosent A verduidelik 'n konsep in een taal en som dan kortliks op of herhaal kernaspekte in die ander taal. Dosent B herhaal omtrent elke sin in die ander taal. In beide klasse was daar tekens van lae interaksie. Wat taalgebruik deur die dosente betref, was dit in beide gevalle ooglopend dat hulle gemaklik en natuurlik Afrikaans praat. In beide gevalle was hulle gebuik van Engels plek-plek stram en onidiomaties. Hulle soek telkens vir die Engelse ekwivalent en moet dan herfraseer of selfs aandui dat die woord hulle vir die oomblik ontgaan het.

In groep A het die tolk per geleentheid tydens die pouse met die dosent gepraat en gevra dat hy harder praat en die vrae van studente herhaal, omdat dit meestal onhoorbaar was. Wanneer hy dit gedoen het, het die atmosfeer in die klas merkbaar meer "lewendig" geword. Wanneer die tolk 'n student per geleentheid versoek het om 'n vraag te herhaal, was daar weer 'n merkbare oplewing in die atmosfeer. Dit het telkens ook aanleiding gegee tot ' $n$ verandering in die trant van kommunikasie en 'n minder monotone lewering deur die dosent.

'n Student wat nie van die tolking gebruikgemaak het nie, het aantekeninge op sy skootrekenaar getik. Ek het gemerk dat die student ooglopende vertaalfoute maak. Hy het byvoorbeeld "regsgeldige doelwit" met legal right, "fisiese sake" met physical integrity en "uitdruklike toestemming vir spesifieke skade" met intentional consent to harm, vertaal. ${ }^{22}$

Uit waarneming in T-opsieklasse is een van die mees betekenisvolle gevolgtrekkings die feit dat kontekstuele leidrade soms verlore gaan. Dosent A sê byvoorbeeld: "Hierdie deel van die werk is minder belangrik ... ons gaan dit slegs opsommenderwys bespreek" of , "U kan slegs een saak vir Dinsdag lees ... die ander sake hoef u nie so in diepte te lees nie" of, "Ek gaan nou handel met besonderhede wat nie in die handboek is nie ... u sal moet afskryf". Hy behandel skryfstyl in die beantwoording van eksamenvraestelle en die korrekte terminologie vir sekere konsepte slegs in een taal. Hy sê byvoorbeeld: "Onthou in die Strafreg kan 'n handeling sélf onregmatig wees, maar in Deliktereg is dit nie so nie. Daar moet strafregtelike gevolge wees." Hy herhaal dit nie in Engels nie. Omdat dosent B weer bykans alles herhaal, gee dit aanleiding tot ' $n$ gefragmenteerde, frustrerende aanbieding. Sy sal byvoorbeeld sê: “... it is void ... dit is ongeldig ... it is void" of "artikel 242 ... section 242 of the Children's Act...". Tolking binne hierdie taalopset is futiel.

\footnotetext{
${ }^{22}$ Die betrokke student se toestemming is verkry om hierdie inligting te gebruik.
} 
Daar was ook voorbeelde van waar die voorkennis van die tolk die inspanning ${ }^{23}$ op 'n gegewe oomblik verlig het en die kwaliteit van die tolkproduk verhoog het. Die tolk ken die betekenis van die term "estoppel" as die dosent dit verduidelik. Sy kan dus die uitinge antisipeer. Dit vergemaklik haar taak aansienlik. Die dosent praat van "speelkinders". Die tolk kry nie onmiddellik die Engelse ekwivalent nie en gebruik die Latynse term "spurii". Die tolk was in staat om die term te onthou omdat dit in die lesingmateriaal voorgekom het. Die dosent sê: "betaal in paaiemente". Die tolk sê: "pay in monthly installments". Die dosent sê: "ware toedrag..." en die tolk tolk "The real age of the minor." Dit was moontlik omdat die tolk die feite van die saak geken het. Die dosent sê: “... bloedtoetse is nogal ... hulle steek 'n naald in jou arm..." Die tolk sê: “...blood tests are rather ... 'invasive'... they put a needle into your arm”.

\section{Gevolgtrekking}

Die studente in die huidige studiekonteks kom uit verskillende taalagtergronde en beskik oor 'n wisselende mate van akademiese taalvaardigheid. Uit groep A was daar sewe studente uit die totale groep wat een van die twee onderrigtale nie as eerste óf tweede taal het nie. Daar is beduidend groter verskille in taalvaardigheid onder Engels-eerstetaalsprekers as onder Afrikaans-eerstetaalsprekers.

\subsection{T-opsie}

Die meerderheid $(75 \%)$ van die respondente het die T-opsie as positief ervaar. Positiewe kommentaar op die T-opsie het verwys na die waarde van individuele meertaligheid en die bevordering daarvan. ${ }^{24}$ Vir die geslaagdheid van dié taalmodel is vergelykbare taalvaardighede in die twee onderrigtale egter ' $n$ voorwaarde. Uit die groep wat 'n positiewe ervaring aangedui het, het $37 \%$ egter negatiewe kommentaar daarop gelewer. Daar was in die kommentaar op die T-opsie 'n voortdurende transgressie tussen positief en negatief wat tekenend is van die polemiese aard daarvan. Dit is duidelik dat die T-opsie, hoe dit ook al toegepas word, kritiek by 'n sekere segment ontlok en aanleiding gee tot 'n toutreksituasie vir meer van jou eie taal. Wat 'n goeie toepassing behels, verskil na gelang van die taalbehoeftes van elke student. Sodra daar 'n persepsie is van meer van die "ander" taal, veroorsaak dit negatiwiteit. Vyf en twintig persent $(25 \%)$ van die respondente uit groep A het aangedui dat hulle dit as negatief ervaar. Kritiek teen die T-opsie was in hoofsaak gemik op die herhaling en die tyd wat daardeur in beslaggeneem word. Dit was ook ten koste van 'n meer indiepte verduideliking. Die voortdurende onderbreking en "terugbeweeg" in die lesing het gelei tot 'n verlies aan fokus en konsentrasie. Die grootste negatiwiteit kom uit die groep van Engelse eerstetaalsprekers wat probleme met taal ervaar. Dosente ervaar ook 'n frustrasie met dié taalmodel en voel dat dit die aanbieding en interaksie tydens lesings bemoeilik. Hierdie sentimente is gestaaf deur waarneming.

\footnotetext{
${ }^{23}$ Hierdie konsep verwys na Gile se Inspanningsmodel (1995).

${ }^{24}$ Die bevorderlikheid van 'n tweetalige model (of tolking) vir individuele meertaligheid het buite die bestek van die studie geval. Clausen (2011:98) het opgemerk dat daar nie bewyse daarvan bestaan in empiriese navorsing nie. Hoewel dit een van die doelstellings van die Tolkloodsprojek (2012) was, is hierdie aspek nie bewys of weerlê nie.
} 


\subsection{Tolking}

Die ervaring van die tolking was oorwegend positief. Drie en tagtig persent (83\%) uit die groep wat die tolkdiens gebruik het, het die tolking as positief ervaar. Engelse gebruikers sal die diens "waarskynlik" of "definitief" gebruik. Afrikaanse gebruikers is bykans in die helfte verdeel hieroor. Nege en sewentig persent (79\%) uit die totale groep het gemeen dat tolking in klasse nodig is. Hierdie syfer is vergelykbaar met Clausen (2011:89) se resultate wat getoon het dat $71 \%$ van die studente tolking in klasse as "nodig" gesien het. Uit die statistiese resultate is dit duidelik dat die positiewe ervaring van die tolking tot 'n groot mate toegeskryf kan word aan die hoë kwaliteit van die tolking.

Dit het duidelik na vore gekom dat Engels-eerstetaalsprekers wat aan die proefneming deelgeneem het, van die tolkdiens wóú gebruik maak. Afrikaanse studente wat in die meeste gevalle beide die onderrigtale verstaan, het tolking nie werklik nodig nie. Die negatiewe ervaring kom vanuit dié groep. Gile (1995:37) wys daarop dat die persepsie van tolking verband hou met die motivering van elke individuele luisteraar. Die groep vir wie die tolking waarde ingehou het en wat dit nodig gehad het, het 'n positiewe ervaring daarvan gehad.

Negatiewe ervarings het oorwegend verband gehou met die feit dat die tolking in die T-opsie plaasgevind het. Studente wat al twee die onderrigtale magtig is, het die tolking as frustrerend ervaar, omdat hulle telkens die oorstukke moes opsit en afhaal.

Tolking binne die huidige studiekonteks was veeleisend en het bekwaamheid en ervaring geverg. Die belangrikheid van hoë taalvaardigheid in beide die onderrigtale en voorkennis van die regsveld en vakterminologie was ooglopend. Die waarde van 'n kort volgafstand tussen die oorspronklike en die getolkte uiting was duidelik, veral in die persepsie van kwaliteit en dat die tolk "gelyk" met die dosent gepraat het. In tegniese kommunikasie is dit belangrik dat tolke die dosent se praatspoed handhaaf.

Dit was duidelik dat 'n opvoedkundige tolk nie 'n eendimensionele, vooraf- gedefinieerde rol kan of behoort te vervul nie. Die feit dat die tolke benewens hulle taalvaardighede ook oor vakkennis en kennis van die konteks beskik het, het hulle rol in die interaksie meer sigbaar gemaak. Dit is bewys van wat Turner (2004:184) bedoel as hy die tolk 'n medewerker in die kommunikasieproses noem, in die huidige geval, die proses van onderrig en leer. Dit sluit aan by Dickinson en Turner (2008:241) se beroep op tolke om maniere te ondersoek om die praktiese sy van hulle werk aan gespreksgenote te verduidelik. "It is an essential part of the interpreter's professionalism to emphasize their visibility so that all participants are aware of their presence and can make informed decisions about the way they react and interact thus ensuring that they become an active part of the interpreting process itself." In die huidige proefneming was die waarde van goeie kommunikasie tussen die dosent, die navorser/tolk en die gebruikers ooglopend. Hierdie feit, sowel as die feit dat die navorsingsproses deurgaans verduidelik is, het vertroue in die tolking verhoog.

Uit die data kon ek as navorser die afleiding maak dat, in sekere kontekste en op sekere voorwaardes, die tolk, in samewerking met die ander rolspelers, die kommunikasie só kan aanpas dat dit die aandag van studente fokus en hulle meer aktief betrokke maak by die leerproses. Met verwysing na die hipotese van die studie het ek bevind dat studente wat van OT gebruik gemaak het van mening was dat hulle nou vakinhoud beter verstaan, dat hulle beter met 
die leerkonteks kon identifiseer en dat hulle, binne sowel as buite die klaskamer, tyd in die leerproses bespaar. Hieruit volg dat die unieke eienskappe van OT en die funksies van die opvoedkundige tolk onderrig en leer binne die navorsingskonteks bevorder het.

Vir die optimale toepassing van OT binne die studiekonteks, behoort dit egter aan sekere voorwaardes $^{25}$ te voldoen:

- Tolke moet oor 'n hoë taalvaardigheid en verkieslik oor die tersaaklike vakkennis beskik.

- Tolke moet ervaring en kennis van klaskamerdiskoers en die leerkonteks hê.

- Daar moet goeie saamwerkverhoudinge tussen dosente, studente en tolke wees.

- Tolke moet die vrymoedigheid hê om die kommunikasie binne te dring en 'n aktiewe rol te speel indien dit suksesvolle kommunikasie sal bevorder.

- Tolke moet as volwaardige kommunikasievennote gesien word.

Tolking binne T-opsieklasse is nie optimaal nie. Die dosent moet verkieslik in sy/haar eerste taal klasgee. Tolke kan die lesing dan in die ander taal tolk vir studente wat nie vaardig genoeg is in die taal van die spreker nie. Voorsiening kan sover doenlik vir alle taalgroepe binne so ' $n$ model gemaak word.

Tersiêre klaskamers word gekenmerk deur verskille in status, voorkennis, opvoedingspeil, kultuur en aansienlike verskille in akademiese taalvaardighede. Die realiteit in T-opsieklasse is dat dit aanleiding gee daartoe dat begrip verlore gaan in die leerproses: "Entire sentences become unknowable". ${ }^{26}$ Courtney Cazden, skrywer van die seminale werk Classroom Discourse (2001:76) kom, wat taal in klasse betref, tot die volgende slotsom: "One condition essential to learning must remain the same: to communicate, to understand and to be understood - this condition has to be kept constant despite differences."

\section{Bronnelys}

Angelelli, C.V. 2004. Revisiting the interpreter's role. Amsterdam/Philadelphia: John Benjamins.

Berg, B.L. 2009. Qualitative research methods for the social sciences. 7de uitgawe. Kaapstad: Allyn \& Bacon.

Blaauw, J. 2012. Persoonlike onderhoud. 21 Februarie, Fakulteit Ingenieurswese: Universiteit Stellenbosch.

Bothma, R. en Verhoef, M. 2008. Assessing the role of the interpreter in facilitating classroom communication. In M. Verhoef en T. du Plessis (reds.). Multilingualism and educational interpreting: Innovation and delivery. Pretoria: Van Schaik. pp. 32-46.

Boughey, C. 2000. Multiple metaphors in an understanding of academic literacy. Teachers and teaching: theory and practice 6(3): 279-290.

\footnotetext{
${ }^{25}$ Slegs enkele voorwaardes word hier gegee. Vir 'n volledige lys sien Brewis (2012:163).

${ }^{26}$ Hierdie aanhaling behoort aan 'n respondent uit groep B en word volledig weergegee in Brewis (2012:123).
} 
Brewis, C. 2012. Die bevorderlikheid van opvoedkundige tolking vir effektiewe onderrig en leer binne die konteks van die Fakulteit Regsgeleerdheid aan die Universiteit Stellenbosch. Magistertesis. Stellenbosch: Universiteit Stellenbosch.

Cazden, C.B. 2001. Classroom discourse. The language of teaching and learning. 2de uitgawe. Portsmouth, NH: Heinemann.

Clausen, M. 2011. Die potensiaal van tolking in die Fakulteit Lettere en Sosiale Wetenskappe (US): Die Departement Maatskaplike Werk as gevallestudie. Magistertesis. Stellenbosch: Universiteit Stellenbosch.

Cummins, J. 1991. Conversational and academic language proficiency in bilingual contexts. Aila Review 8: 75-89.

Cummins, J. 2006. Identity texts: The imaginative construction of self through multiliteracies pedagogy. In O. Garcia, T. Skutnabb-Kangas en M.E. Torrez-Guzman (reds.). Imagining multilingual schools: Language in education and globalization. Clevedon: Multilingual Matters Ltd. [Internet].

Beskikbaar: http://site.ebrary.com/lib/stellenbosch/doc?id=10132114\&ppg=61. (6 Mei2011).

Dickinson, J. en Turner, G.H. 2008. Sign language interpreters and role conflict in the workplace. In C. Valero-Garcés en A. Martin (reds.). Crossing borders in community interpreting: Definitions and dilemmas. Amsterdam/Philadelphia: John Benjamins. pp. 231242.

Elghezouani, A. 2004. Professionalisation of interpreters: The case of mental health care. In C. Wadensjö, B.E. Dimitrova en A. Nilsson (reds.). The critical link 4. Amsterdam/Philadelphia: John Benjamins. pp. 193-204.

Gambier, Y., Gile, D. en Taylor, C. (reds.) 1997. Conference Interpreting: Current trends in research. Amsterdam/Philadelphia: John Benjamins.

Gile, D. 1995. Basic concepts and models for interpreter and translator training. Amsterdam/Philadelphia: John Benjamins.

Gile, D. 2011. Educational Interpreting, E-pos aan I. Cilliers, 10 April. Beskikbaar E-pos: isa@iafrica.com.

Jacobs, C. 2005. On being an insider on the outside: new spaces for integrating academic literacies. Teaching in Higher Education 10(4): 457-487.

Kent, S.J. 2007. A discourse of danger and loss: Interpreters on interpreting for the European Parliament. In S. Hale, U. Ozolins en L. Stern (reds.). The critical link 5: Quality in interpreting - a shared responsibility. Amsterdam/Philadelphia: John Benjamins. pp. 55-70.

Mantero, M. 2002. Evaluating classroom communication: In support of emergent and authentic frameworks in second language assessment. Practical assessment, research and evaluation 8(8): 1-6. [Internet]. Beskikbaar: http://PAREonline.net/getvn.asp? $v=8 \& n=8$ (8 Maart 2011). 
Marais, H.C. 2008. Vergelyking van twee taalondersoeke onderneem vir die Universiteit van Stellenbosch. Stellenbosch: Universiteit Stellenbosch.

Marschark, M., Peterson, R. en Winston, E.A. (reds.) 2005. Sign language interpreting and interpreter education. New York: Oxford University Press.

Marschark, M, Sapere, P., Convertino, C. en Seewagen, R. 2005. Educational Interpreting: Access and outcomes. In M. Marschark, R. Peterson en E.A. Winston (reds.) Sign language interpreting and interpreter education. New York: Oxford University Press. pp. 57-83.

Mouton, J. 2001. How to succeed in your master's and doctoral studies: A South African guide and resource book. Pretoria: Van Schaik.

Olivier, H. 2008. Process, product and performance: Differences between conference interpreters and educational interpreters. In M. Verhoef en T. du Plessis (reds.). Multilingualism and educational interpreting: Innovation and delivery. Pretoria: Van Schaik. pp. 99-113.

Pöllabauer, S. 2004. Interpreting in asylum hearings: Issues of saving face. In C. Wadensjö, B.E. Dimitrova en A. Nilsson (reds.). The critical link 4. Amsterdam/Philadelphia: John Benjamins. pp. 39-52.

Pöchhacker, F. 2004. Introducing interpreting studies. Londen en New York: Routledge.

Pöchhacker, F. 2011. Educational interpreting, E-pos aan I. Cilliers, 21 Maart. Beskikbaar Epos: isa@iafrica.com.

Reason, P. 1998. Political, epistemological, ecological and spiritual dimensions of participation. Studies in cultures, organizations and societies 4: 147-167.

Saunders, M., Lewis, P. en Thornhill, A. 2007. Research methods for business students. 4de uitgawe. Edinburg: Prentice Hall.

Street, B.V. 2003. What's new in New Literacy Studies? Critical approaches to literacy theory and practice. Current issues in comparative education 5(2): 77-91.

Tebble, H. 2007. What can interpreters learn from discourse studies? In S. Hale, U. Ozolins en L. Stern (reds.). The critical link 5: Quality in interpreting - a shared responsibility. Amsterdam/Philadelphia: John Benjamins. pp. 201-220.

Turner, G.H. 2004. Professionalisation of interpreting with the community: Refining the model. In C. Wadensjö, B.E. Dimitrova en A. Nilsson (reds.). The critical link 4. Amsterdam/Philadelphia: John Benjamins. pp. 181-192.

Turner, G.H. 2005. Toward real interpreting. In M. Marschark, R. Peterson en E.A. Winston (reds.). Sign language interpreting and interpreter education. New York: Oxford University Press. pp. 29-56. 
Universiteit Stellenbosch. 2012. Navorsingsprojek: Die implementering van opvoedkundige tolking aan die Universiteit Stellenbosch. Stellenbosch: Taalsentrum, Universiteit Stellenbosch.

Van Schalkwyk, S. 2010. When the teacher becomes the student: The acquisition of academic literacy revisited. Acta Academica Supplementum 1: 201-222.

Verhoef, M. 2008. Accounting for paralanguage and non-verbal communication in the educational interpreting service rendered at the North-West University. In M. Verhoef en T. du Plessis (reds.). Multilingualism and educational interpreting: Innovation and delivery. Pretoria: Van Schaik. pp. 160-178.

Verhoef, M. 2010. Taalbeleid en onderrigtaalmodus aan die Noordwes-universiteit. In FW De Klerk Stigting. ' $n$ Studie oor Afrikaans op universiteitsvlak. Panorama: FW De Klerk Stigting. pp. $168-182$.

Verhoef, M. en Blaauw, J. 2009. Towards comprehending spoken-language educational interpreting as rendered at a South African university. In J. Inggs en L. Meintjies (reds.). Translation studies in Africa. Londen en New York: Continuum. pp. 204-222.

Verhoef, M. en Du Plessis, T. (reds.). 2008. Multilingualism and educational interpreting: Innovation and delivery. Pretoria: Van Schaik.

Wadensjö, C. 1998. Interpreting as interaction. Londen en New York: Longman.

Wadensjö, C., Dimitrova, B.E. en Nilson, A. (reds.) 2004. The critical link 4. Amsterdam/Philadelphia: John Benjamins.

Wenger, E. 2000. Communities of practice and social learning systems. Organization 7(2):225246. 